\title{
The origins of new quotative expressions: the case of Paris French
}

\author{
JENNY CHESHIRE $^{1}$ and MARIA SECOVA ${ }^{2}$ \\ ${ }^{1}$ Queen Mary University of London, UK and ${ }^{2}$ The Open University, UK
}

\begin{abstract}
We analyse genre in the speech of young people with multi-ethnic friendship groups in Paris in order to address the as yet unresolved question of whether new quotatives equivalent in meaning to English BE LIKE result from simultaneous independent parallel developments in languages other than English or from a process of calquing. We conclude that French quotative genre results from independent internal developments but that it enters the French quotative system in the same way that BE LIKE entered the English system, driven by the meanings of 'similarity' or 'approximation' that are shared by the lexical item genre in a range of syntactic categories. We propose that in order for a new similarity quotative to emerge, a lexical item with a meaning of 'similarity' or 'approximation' must become syntactically multifunctional, and that the use of that lexical item must reach a critical frequency threshold. In the case of genre we suggest that the necessary increase in frequency results from the development of the lexical item into a discourse marker. We also analyse another new French quotative, ETRE LA, a sequence that we find is used to highlight activity of many kinds (including, but not confined to, spoken behaviour). The trajectory followed by each of the new quotative expressions conforms to De Smet's proposals about how linguistic innovations spread through the grammar.
\end{abstract}




\section{INTRODUCTION}

One of the most dramatic linguistic changes of the last few decades is the rapid emergence of new quotative expressions in young people's speech. English BE LIKE, as in (1), is the best known of the new forms used to introduce reported speech and thought, but similar expressions have appeared in other languages. We give three examples from Spanish, Norwegian and Finnish in (2) to (4), but further examples from many other languages could have been given.

(1) and there was a cop and police car right there and I started screaming and I'm like "go and get them" (Cheshire and Fox 2007)

(2) tu ves que con Javi tu vas a tener confianza en plan "tia pues adelante" (you see you will feel safe with Javi like "go ahead then man" (Palacios Martínez 2014)

(3) og han er liksom, “å vi må bastille tog billet” og er helt hyper (and he ’s like, "oh we must order our train tickets" and is totally hyper) (Hasund et al 2012: 51)

(4) ja sit mä olin niinku, "Että herrajjumala et voi olla totta"(and then I was like, "oh my God I can't believe it”) (Fleischmann 1999; quoted in Levey et al 2013: 230).

In this paper we advance our understanding of how new quotatives such as these arise by analysing the quotative expressions used by young French speakers living in the banlieues of Paris. We provide an answer to the as yet unresolved question of whether the simultaneous emergence of new 'similarity' quotatives (Buchstaller and van Alphen 2012:xiv, Buchstaller 2014:20) in languages other than English results from independent parallel developments in the different languages, or 
from indirect pragmatic borrowing from English involving the transfer of a function (quotation) rather than a form (Andersen 2014:18, Buchstaller 2014:19). Our analysis of the new French quotative genre concludes that it results from an independent development, but that it enters the French quotative system in the same way that BE LIKE entered the English system, driven by meanings of 'similarity' and 'approximation' that are shared by the lexical item genre in a range of different syntactic roles. We propose that another new quotative, ETRE LA, has developed alongside non-quotative sequences of the ETRE LA sequence, possibly influenced by the textual and interpersonal functions of the particle là. Together, our analyses not only add to our knowledge of the quotative system in present-day spoken French but contribute to our understanding of the processes that drive the emergence of innovative quotative expressions more generally.

\section{THE DATA}

Other articles in this Special Issue describe the Multicultural London EnglishMulticultural Paris French project (Gardner-Chloros, Cheshire and Secova 20102014) and the young people whose speech makes up our Multicultural Paris French $(M P F)$ corpus. Our analysis in this article is based on the quotative expressions used by 60 of the young Parisians recorded by Maria Secova in natural friendship groups of 2, 3 or 4 speakers, reflecting the social networks and patterns of interaction in the multi-ethnic banlieues. Note that our MPF corpus should be distinguished from the corpus collected at Paris Ouest Nanterre which has the same name (Gadet 2017). The 60 young speakers were aged between 12 and 19; 37 were female and 23 were male. 17 young people were monolingual and of local French origin; their families had lived in Paris for many generations. The remaining 43 were of recent immigrant origin, 
from a wide range of countries including Algeria, Benin, Haïti, Mali, Martinique, Tunisia, Turkey and more. All had been born in France or had lived in France from an early age.

We add a diachronic perspective to our study by analysing interviews from the Corpus de Français Parlé Parisien (CFPP2000), 'Corpus of Spoken Parisian French' (Branca-Rosoff, Fleury, Lefeuvre and Pires 2012; http://cfpp2000.univ-paris3.fr). This corpus was collected in the Paris area between 2006-2014, and amounts, to date, to approximately 50 hours of speech. It is similar to the $M P F$ corpus in that it is based on informal interviews with self-selected groups of friends or relatives (though some recordings in the $M P F$ corpus diverge from the interview into free, almost unmonitored conversation between friends). The CFPP2000 speakers talk about their daily lives and their attitudes towards their city, and tell stories about past experiences - topics that are also talked about by the $M P F$ speakers. In both cases there is minimal input from the interviewer, and the interview style is largely informal. While the speakers in CFPP2000 come from a wider range of social classes than the speakers in the $M P F$ corpus, the majority of older informants selected for this study come from local families of working-class or lower-middle-class background, largely matching the social composition of our MPF sample.

We recognise that a distribution by age does not necessarily indicate ongoing language change (Buchstaller 2014: 259), but nonetheless it can suggest possible directions of change. Here we use the age distribution to identify potential innovations in young people's speech. 
We extracted all instances of direct quotation from the $60 M P F$ speakers and from 16 CFPP2000 speakers aged between 60 and 88 (2 men and 14 women). We included 'all strategies used to introduce reported speech, sounds, gesture and thought by self or other' (Buchstaller 2006: 5) but excluded false starts, repetitions, unclear speech and reported written French.

In addition to the 'zero form' (see (5) below), where the reported speech or thought occurs without any introduction, the older CFPP2000 speakers mainly use DIRE, 'say', to introduce reported speech (example 6), and SE DIRE, 'think' (literally 'say to oneself'), to introduce reported thought (7).

(5) mais + et c'est vrai que quand on nous voyait revenir dans la cité "où c'est qu'vous avez encore été vous êtes crades et tout" (Jacqueline Pelletier)

(6) ma mère est venue l'visiter et la propriétaire de l'époque lui a dit euh + "nous pouvons vous le louer à une condition c'est que vous nous promettiez que vous n'ayez pas d'enfants" (Yvette Audin)

(7) c'est vrai que la mort de Claude était arrivée très tôt j'me suis dit "j'ai j'ai au moins la chance de n' pas avoir à déménager" (Pauline de Bordes)

Table 1 lists the distribution of quotative expressions for the two age groups. We list separately for older speakers the rare forms c'est/c 'était and FAIRE to show their frequency relative to that of the younger speakers. Other forms occurring infrequently in the CFPP2000 transcripts (of which 6 come from a single speaker) are 
CHANTER, FAIRE COMME CA, FAIRE SIGNE, INTERPELLER, PARLER, POSER LA QUESTION, REPONDRE, TELEPHONER and TRAITER DE.

\section{TABLE 1 HERE}

The Table shows that the young Parisians use DIRE almost half as often as the older speakers. This is partly because of the young speakers' more frequent use of FAIRE (as in (8)), but also because they use five expressions that we assume are new quotatives: the three 'similarity' quotatives GENRE, EN MODE and FAIRE STYLE, illustrated in (9) to $(11)^{2}$, and two demonstrative quotative expressions: ETRE LA, (12), and ETRE COMME CA, (13). Note that there are also four tokens of DIRE genre (14) and FAIRE genre (15). These may represent a transitional internal stage of development of quotative genre, comparable to the sporadic occurrence of English like with SAY, GO and THINK as intermediate stages in the evolving trajectory of BE LIKE (Levey 2007). C'EST/C'ETAIT is illustrated in (16) .

(8) il fait "ouais $<$ rire $>$ hmm bonne nuit" (Lilianne)

(9) on dirait des gamins genre "non j'ai pas deux ans" (Letitia)

(10) et moi en mode euh "ouais vas-y je tombe enceinte" <imitation> (Livia)

(11) et ils font style (.) "oh là là c'est trop simple ils ont des massages des masques et tout" < imitation $>($ Annabelle $)$ 
(12) après j'ai mis juste les chansons du Roi Lion ma sœur et moi on était là "ouais" et tout (Issa)

(13) moi j'ai failli vomir j’étais comme ça < vomiting noises> (Elisa)

(14) mais genre je leur disais genre "ils sont entraînés pour être les meilleurs en danse" et tout ça (Aisatta)

(15) quand je connais personne là bas je peux pas faire genre "ouais nanana tu parles à qui comme ça" (Aimée)

(16) moi le truc qui m'a le plus fait rire c'est (...) "eh cousin (..) je sais pas si xxx xx ta brosse à dent $<$ imitation $><$ rires $>($ Abdel $)$

The fact that FAIRE makes up nearly 30 per cent of the quotatives in young people's speech whereas there is just one token in our CFPP2000 sample is worth a brief comment. Perhaps, like English GO, another 'generic action quotative' (Buchstaller and Van Alphen 2012: xiv), its appearance in the quotative system is cyclical, such that we are now witnessing a reappearance of quotative FAIRE in spoken French. Several of the examples given by Marnette (2006) show that it was certainly used in medieval French. Our focus here, though, is on the quotatives that do not occur at all in older people's speech and that we therefore assume to be innovations. The frequencies of these new quotatives are very low: although genre as a quotative was attested as long ago as the 1990s (Yaguello 1998), together the three similarity quotatives account for only 2.6 per cent of all quotative expressions used by 
the young speakers. Frequencies for the demonstrative quotatives are slightly higher, amounting to almost 4 per cent of all quotatives, but this is still a low proportion.

The 'other' category contains a further 19 verbs: ALLER, PARLER, RIGOLER, EXPLIQUER, REPONDRE, CRIER, APPELER, REPRENDRE, COMMENCER, SORTIR, ENVOYER, TAQUINER, TRAITER, RACONTER, PLEURER, PENSER, SE RENDRE COMPTE, ETRE and METTRE. Most occur only once or twice in the data; some are also used by the older speakers. The diversity is exceptional: it is wider, for example, than reported by Levey et al (2013) for Ottawa French, where there are only 12 different forms. Perhaps the diversity in Paris reflects the low frequencies of the innovative quotatives. For many English-speaking young people BE LIKE is so frequent that it is displacing most other quotative forms in the system. Research in Toronto carried out in 2002, for instance, found that young people rarely used anything other than BE LIKE (Tagliamonte and D'Arcy 2005:263).

We take the low frequencies of the innovative expressions in Paris as an indication that they are not yet well established in the quotative systems of the young speakers. The existence of as many as three new similarity quotatives and two new demonstrative quotatives, similarly, suggests that the system has not yet stabilised. We have heard the new expressions elsewhere in France, and they occur in the internet fora analysed by Davidse and Doyen (2009), but as far as we know their use in other cities has been studied systematically only in Neuhof, Alsace (Marchessou, this volume). We do not know, therefore, how well established they are in the speech of young people elsewhere in France, or even elsewhere in Paris.

The fact that they appear to be in the early stages of emergence in our data means that we have an unusual opportunity to examine the ways in which the new 
forms enter the quotative system, as well as how an item develops a new pragmatic function. In what follows we focus mainly on the most frequent of the new similarity quotatives, GENRE, and then on the most frequent of the new demonstrative quotatives, ETRE LA.

\section{QUOTATIVE GENRE: A CONTACT-DRIVEN CHANGE?}

Circumstantial factors could suggest that quotative genre is a calque on English BE LIKE: a 'convergent development' (Weinreich 1964[1953]) or 'pattern transfer' (Heath 1984); (see Matras 2011 for discussion of contact-induced internal changes of this kind). Most of the young people we recorded were exposed to English in one way or another: they all listened to music from the UK and the USA, most were studying English at school, and many had been to England for study trips or exchange visits. This does not mean to say that they were all proficient in English but, as Petersen (2017: 119) argues with reference to the use of English discoursepragmatic items in Finnish, it is not necessary to be proficient in English for pragmatic borrowing to occur. There is widespread agreement in the literature that speakers can import constructions into their language based simply on 'foreign modes of imitation' (Matras 2011:285).

It is possible, then, that young French speakers have begun to use quotative genre as a calque on English like. Admittedly, we would then expect genre to occur with a supporting empty verb comparable to English BE, but English like sometimes occurs alone to introduce a quote (an example from London is and then we choose them like "you . me . there"; data from Kerswill, Cheshire, Fox and Torgersen 20072010); and, as noted earlier, genre is sometimes used with DIRE or FAIRE (though these are hardly 'empty' verbs). 
However, a closer semantic equivalent to English like is French comme. A quotative expression with comme does occur in our data, ETRE COMME CA (comparable, perhaps, to BE like that in Glasgow; Macaulay 2001), but a more plausible case of convergent development occurs in Canada, where French speakers are of course in greater contact with English than in France and where there may be less resistance to calques from English. In Canada être comme is a frequent quotative expression; in fact, for 20-30 year olds in the Ottawa French Corpus (2008-2009) it is the most frequent quotative, occurring 58 per cent of the time in female speech (Levey et al 2013). Genre and c'est genre also occur in Ottawa as quotatives, but infrequently. Yet although Levey et al do not refute the possible role of external factors in the evolution of ETRE COMME, their comparative analysis of BE LIKE and ETRE COMME suggests that BE LIKE is not the only, nor even the preferred source of ETRE COMME (Levey et al 2013:247).

In fact, from the perspective of semantic equivalence, the noun genre is closer in meaning to the English nouns type, sort or kind than it is to like. Crosslinguistically, 'type' nouns often grammaticalise into adverbials, discourse markers and sometimes even quotative expressions (see Diewald 2006 for German, Rosenkvist and Skärlund 2011 for Swedish, and Mihatsch 2007 for Spanish, Italian and Portuguese). But English sort (of) and kind (of) are less grammaticalised than French genre (Davidse and Doyen 2009), and they rarely occur as quotatives (Aijmer 2002, Davidse and Doyen 2009:142). It is unlikely, therefore, that English sort (of) or kind (of) have influenced the emergence of quotative genre.

For the time being, there is little evidence to support the view that quotative genre is a loan translation from English BE LIKE, or from any other English lexical item. The same may be true for similarity quotatives in other languages. We have 
already noted that the preferred 'similarity' quotative forms in Paris and Ottawa are different, suggesting independent internal developments in the two locations; in Spanish, too, there are different similarity quotative forms in Argentina, where tipo is preferred (Fernández 2017), and Arizona, where Spanish-English bilinguals use como (Kern 2014). Of course, we cannot rule out the possibility that language contact with English has accelerated the emergence of a similarity quotative in French, even if the result is not a direct calque. This, however, has to remain an open question since, as Poplack, Zentz and Dion (2012:250) observe, 'we cannot determine whether contact accelerates change when we do not (and cannot) know what the rate of change would have been in its absence, ${ }^{4}$.

\section{QUOTATIVE GENRE AS AN INDEPENDENT DEVELOPMENT}

In contrast, our data provides solid evidence for seeing quotative genre as an independent development in French. Our data suggest that it is linked to the development of genre as a discourse marker, as we will show, but unlike other researchers (for example, Fleischman and Yaguello 2004: 141) we do not see it as deriving directly from the discourse marker. Instead, our analysis indicates that the emergence of the quotative function occurs when speakers begin to use the lexical item genre in an increasing number of syntactic categories and pragmatic functions, including those of the discourse marker. Young speakers in the MPF corpus use genre in each of its syntactic categories, both old and new, to introduce a quote.

We can see how the newer syntactic categories of genre develop over time by analysing its use by different generations of speakers. We divided those CFPP2000 speakers who use genre into six 10-year divisions corresponding to their date of birth 
(when known). Table 2 shows the syntactic functions of genre in their speech; we have added speakers in the $M P F$ sample in the last row of Table 2.

\section{TABLE 2 ABOUT HERE}

The numbers in Table 2 are tantalisingly low, to the extent that the Table might be better treated as an implicational scale. Genre is not a frequent word in the data; 12 of the CFPP2000 speakers do not use genre at all and, as we will see later, even as a discourse marker and discourse particle it is far less frequent in young people's speech than like in English, with which it is often compared (for example by Dufaye 2016:59). Nonetheless, Table 2 confirms the diachronic development of genre that others have proposed. Most scholars assume that the earliest uses of genre are as a noun (e.g. Danon-Boileau and Morel 1997, Fleischman and Yaguello 2004:130, Secova 2011, Davidse et al 2013, Dufaye 2016, Isambert 2016). For the seven older age groups in CFPP2000 this is by far the most frequent use of genre. They sometimes use genre as a simple noun (17) or in fixed expressions such as bon genre (18), but more often genre is the head of a binomial Noun Phrase of the type $[$ determiner + genre $+d e+\mathrm{NP}]$, with the second noun phrase designating a superordinate class, as in (19) and (20).

(17) je trouve qu'on qu'il y a un mélange des genres quand même (Pierre-Marie Simo)

(18) Julie: au collège t'as onze ans enfin j' dirais mettre des talons 
Katia: non mais en troisième quand t'es en troisième c'est bon genre non mais il suffit qu'tu mettes une jupe

(19) non mais c'est ceux qui-z-ont c'genre de chiens c'est ceux qui travaillent dans la sécurité (Abdel Hachim)

(20) non mais ça se voit pas en fait c'est <rires> (.) ils sont physiquement c'est le même genre de physique et tout (Aimée)

The binomial construction is often taken to be the source of more recent developments of genre, by analogy with English sort of (Davidse et al 2013). The argument is that in later developments the second noun of the binomial construction becomes the head, and the 'type' or 'category' it refers to is ad hoc, set up contextually by the speaker. Davidse et al (2013) point out that in these cases the first noun, genre, can be substituted by un tel, and genre has a qualifying function, 'toning down' membership of a category and often marking the phrase as ironic or humorous. There are some examples of this kind in the $M P F$ corpus, but not in the speech of the older Parisians. In (21), for example, from the $M P F$ corpus, genre is clearly a noun, but the head of the noun phrase is pantalon, not genre. Un tel pantalon could be substituted for ce genre de pantalon; and, in line with Davidse et al's (2013) observation, the phrase is marked as humorous, not only by the content of the quote but also by the non-lexicalised sound before the repetition.

(21) J'étais là "pourquoi tu mets ce genre de pantalon $<$ bruit de bouche> pourquoi tu mets ce genre de pantalon!" (Magali) 
Davidse et al argue that uses of this kind represent illustrate the semantic weakening of the noun genre. Instead of indicating that what follows is a superordinate category or type (such as 'chiens' in (19) or 'physique' in (20)), genre now qualifies or hedges the following noun. Here genre could be omitted, but it is not redundant since it enhances the expressivity of the noun phrase (Mihatsch 2007:230). Although there are no uses of this kind in our CFPP2000 sample, we do find the noun genre used with a hedging function in a different construction: when followed by an infinitival complement. Here, too, genre tones down membership of a category, and its meaning is weakened to 'approximation'. Thus in (22), Micheline's repetition of on est and $\grave{a}$ shows that she is struggling to find the right phrase; having uttered it (à chercher la compagnie à avoir), she seeks the understanding of her interlocutor with tu vois, and then clarifies what she has just said by adding à s'mettre au courant. In (23), faire attention is a humorous description of the behaviour of Valentine and Thérèse's school teacher. In these uses, then, we see some semantic weakening of the noun genre in the speech of older speakers, which foreshadows future developments in younger speakers.

(22) Nous on s'intéresse beaucoup au quartier parce que nous on est on est du genre à à à à chercher la compagnie à avoir tu vois à s'mettre au courant (Micheline Rosier)

(23) Valentine Testanier: lui il était même un peu du genre euh:: faire attention Thérése le Vern: $\quad$ Monsieur Mignan

Table 2 shows that older speakers use genre with a preposition-like role as well as a nominal. This is attested since at least the mid-nineteenth century (Isambert 
2016:88). It is important for the future development of other syntactic roles because here genre often occurs without a determiner, thus losing its marking as a noun and paving the way for it to be used in other syntactic positions and in other syntactic categories. In fact, in the CFPP2000 transcripts some determiners of the noun genre are represented as $<l^{\prime}>$ or $<d^{\prime}>$, indicating some phonetic reduction that perhaps heralds the loss of nominal function. The preposition-like uses in CFPP2000 (24) and the $M P F$ corpus (25) are always without de; elsewhere, however, preposition-like uses of genre have been noted as sometimes occurring with $d u$ (Davidse et al 2013; Isambert 2016:89).

(24) y avait plusieurs bistrots euh tous les anciens commerces genre crèmerie fromagerie boucherie boucherie-chevaline (Leo Valentin)

(25) pour moi riche c'est d'acheter des trucs genre Dior Chanel et tout enfin les grandes marques (Frederique)

Thus the older age groups shown in Table 2 already use genre with some semantic weakening and the beginnings of syntactic flexibility. However, with the single exception of a discourse marker use by one speaker born in the 1940s, it is only speakers born in the 1970s who use it in further different syntactic categories, in all of which genre now has the meaning of approximation or similarity. As an adverbial, genre occurs before a quantified noun or adjective, with an approximative meaning (26).

(26) le Texas ça fait genre douze fois la France (Nadia) 
Fleischman and Yaguello (2004: 130) note that nowadays 'resourceful French speakers enhance the connective capacity of genre with que, thereby enabling it to function as a kind of generic subordinator and thus increasing its syntactic scope'. In our data, (27) is the only token of genre que; it is immediately followed by the semantically equivalent c'est comme si, as if the speaker corrected herself. Here, genre has the meaning of comparison.

(27) ma petite soeur qui a treize ans elle adore parler de ça avec sa tante genre que c'est comme si c'était sa sa grande soeur en fait (Mehda)

There are a few tokens in our data of CFPP2000 speakers born from the 1970 s on using genre as a discourse marker (28) and discourse particle (29) ${ }^{5}$, but the proportion greatly increases for the $M P F$ speakers.

(28) j'étais au téléphone avec elle (.) après (.) genre j'allume mon téléphone (.) et d'un coup le téléphone il est tombé tu vois (.) dans l'eau sans faire exprès (Christine)

(29) il y a tous les casinos il y a le Venise genre avec des gondoles et tout (Christophe)

The $M P F$ speakers also use genre as a filler (30) and, of course, as a quotative expression, as we have already seen. 
(30) Fernand c'était un italien (.) et genre (.) et genre qu'est-ce que je veux dire (.) et en fait ils étaient super proches (Maeva)

Table 3 is a summary of the syntactic and discourse-pragmatic functions of genre that were displayed in Table 2. We follow Davidse and Doyen (2009) in drawing an overall distinction between NP-internal uses of genre and NP-external uses. NP-internal functions are those where genre functions more or less as a noun; they include those we labelled in Table 2 as simple noun, binomial noun, preposition and $d u$ genre + infinitive, as well as fixed expressions containing genre. NP-external uses are those we have categorised as adverbials, discourse particles and discourse markers, and also quotatives.

\section{TABLE 3 HERE}

Table 3 shows clearly the sudden surge in NP-external uses of genre amongst speakers born in the 1970 s, with the number greatly increasing for those born from the early 1990s on. Davidse and Doyen's (2009) comparison of adult and teenage uses of genre in internet fora revealed a similar pattern; they comment (2009:142) that 'strong innovation, detachment from NP-structure and semantic shift is very much situated in the teenage data'. We stress, however, that in our data detachment from NP-structure and semantic shift are already apparent in the speech of older Parisians, albeit to a lesser degree; witness the use of genre as a quasi-preposition with no determiner, and in an infinitival complement construction with a hedging function.

What is important for our understanding of the emergence of new quotative expressions is that some of the $M P F$ speakers co-opt each of the syntactic categories 
of genre, both old and new, to introduce a quote. In (31), for example, the noun $(d u)$ genre has this function.

(31) je sais pas c'était trop cramé (.) mais rien que du fait que (.) les publications c'était du genre (.) "ouais tu m(e) manques" ouais nanana (.) nanana (.) nanana (Lynne)

The first appearance of quotative genre in CFPP2000, by a male speaker born in 1975 , is also the noun:

(32) c'est pas une influence négative du genre "tiens si t'arrêtais de travailler euh fais comme nous" c'est pas tout à fait comme ça (Pierre-Marie Simo)

Sometimes quotative genre resembles the preposition genre: thus in (33) the quote represents a way of speaking that is a kind of grand air, in the same way that Dior and Chanel in (25) above represent a truc.

(33) il y a quelqu'un de la cité nanana direct elles sont là à prendre des grands airs genre "ah tu viens de la cité ah d'accord" < imitation> (Aimée)

As a discourse marker, genre occurs in a range of collocations and sequences. As mentioned above, it sometimes follows a traditional quotative verb or the dummy verb ETRE (34). Here, genre focuses on or, sometimes, hedges the following reported quote: 
(34) et il y en a un autre il est genre "ah" < imitation> (Lynne)

Quotative genre also occurs with a preceding c'est, as in (35). Perhaps, like English it's like, this marks the speaker's stance or attitude (Fox and Robles 2010).

(35) avant pendant l'été je trainais avec eux dehors (.) c'est genre "oui je suis bien là" et tout (Lorie)

Elsewhere the discourse marker genre follows an adjective; the quote then elaborates or exemplifies the quality referred to by the adjective:

(36) c'est encore l'époque où les gens ils voyaient un noir ils sont choqués genre "oh (.) un noir ?" < with mimesis> (Jordan)

Finally, quotative genre occurs with a demonstrative construction:

(37) il dit ça comme ça genre "putain il pleut heu" < voix désinvolte> (Suzanne)

In all these examples the approximative meaning of genre drives its use as a quotative expression. Güldemann (2001) notes that many forms used as quotatives are 'notoriously polyfunctional outside the quotative frame'; as we have seen, this is now the case for genre. Buchstaller (2001) further argues, with reference to English BE LIKE, that the shared meanings of like in its different syntactic categories produce a 'syntactic-semantic field' of mutually overlapping and reciprocally reinforcing functions which are relevant to the emergence of the quotative function. The same can 
now be said of genre, whose newer functions all have the meaning of approximation, similarity or comparison. It is understandable that genre is often compared to English like, since it is now very similar in terms of its semantics and, in its newer roles, its syntax. There is a parallel in German, too, where so has recently emerged as both a discourse marker and a quotative and where, according to Wiese (2011), each has followed a separate developmental pathway, with both usages part of a network of meanings of approximation and similarity.

Thus our analysis does not support the views of previous researchers who see the quotative function of genre as deriving from the discourse marker function (for example, Fleischman and Yaguello 2004:141). Instead, quotative genre emerges once the lexical item genre becomes syntactically multifunctional, a property that is typical of new similarity quotative expressions in other languages. Young speakers in Paris harness genre in all its syntactic roles, both old and new, as a quotative expression.

Nevertheless, Table 2 shows that the discourse marker and discourse particle functions are the most frequent ones for the $M P F$ speakers, accounting for more than half the total number of tokens of genre in their speech. And although in the $M P F$ data genre in a range of syntactic categories functions as a quotative, it is the more frequent discourse marker that is most often used to introduce a quote, as Table 4 shows.

\section{TABLE 4 ABOUT HERE}

Even though we do not see the quotative as deriving directly from the discourse marker function, the frequency with which the discourse marker and discourse particles occur in young people's speech is, we argue, very important for 
the development of the quotative function, since it increases the overall frequency with which the 'syntactic-semantic' network for genre occurs.

Tables 2 and 3, above, indicated that the newer functions of genre all emerged in Paris between 1970 and 1980. Table 5 confirms that this period saw a tenfold increase in the use of the discourse marker genre. The early uses of quotative genre appear at this time too, as Table 2 showed. We see in Table 5 that the frequencies of the discourse marker and discourse particle genre are continuing to increase in Paris, albeit slowly. Quotative genre is also gradually increasing in frequency, as the data from the MPF speakers shows.

\section{TABLE 5 HERE}

A comparison with the English-speaking world shows that a similar surge in the frequency of the discourse marker like co-occurred with the entry of BE LIKE into the quotative system. Table 6 shows, for example, a dramatic increase in the use of discourse marker like in London between speakers born in the 1950s and speakers born in the 1980s; as far as we know, quotative BE LIKE emerged in London during the same period. In Toronto, too, there was a surge in frequency of the discourse marker like at the time when quotative BE LIKE appeared (D'Arcy 2005: 41, 86, Tagliamonte and D'Arcy 2009:82). It is also relevant that Spanish-English bilinguals in Arizona did not use como as a quotative until the 'similarity' discourse marker como had developed (Kern 2014).

\section{TABLE 6 HERE}

However, the overall frequency of genre as a discourse marker is still very low compared to that of like in London (compare Tables 5 and 6). In London, even 
speakers aged over 70 use the discourse marker like more often than young people in Paris use the discourse marker genre. We think this explains why quotative genre is infrequent in our Paris data compared to quotative BE LIKE in the English-speaking world: the overall frequency of the lexical item genre is much lower than that of the lexical item like. Nonetheless, as we argued above, the frequency with which young people in Paris use the discourse marker genre relative to the nominal, adverbial and other syntactic roles of genre increases the frequency with which the 'synsem' network for genre occurs in speech, and this in turn increases the likelihood of speakers beginning to use genre as a quotative. We will see in the next section that speakers begin to use the meanings of similarity, approximation or comparison conveyed by genre to introduce the type of quote for which these meanings are particularly apt.

\section{GENRE AS A MEMBER OF THE QUOTATIVE SYSTEM}

More research has been conducted on English BE LIKE than on 'similarity' quotatives in other languages, so it is instructive to compare the entrance of genre into the quotative system with what we know about the well-studied BE LIKE quotative. There is a remarkable consistency in the way that the new quotative expression enters the quotative system in English-speaking communities around the world (see, for example, Buchstaller and D’Arcy 2009 on New Zealand English, English English and American English; Fox (2012) on Multicultural London English; Höhn 2012 and Bogetić 2014 on Jamaican English; Tagliamonte and D’Arcy 2004 on Canadian English). In every locality, BE LIKE is preferred with quotes containing mimetic reenactment, when speakers act out the quote by changing their normal speaking voice or by quoting non-lexicalised sound (Buchstaller 2014: 101, 110). It also seems to 
have started out as a way of reporting internal thought (Buchstaller 2014:110), perhaps because the approximative meaning of like allows speakers to hedge and avoid commitment to the stance, feelings or attitudes, opinions or points of view that they are expressing (Buchstaller and Van Alphen 2012: xv). Hypothetical quotes also favour the use of BE LIKE, presumably because the 'approximation' or 'similarity' meaning of the form makes it a good choice when a speaker does not make clear whether the quote was actually uttered, or merely imagined (Buchstaller 2014: 52). Content of the quote, then, is a "classic factor" (Tagliamonte and D'Arcy 2007) affecting the use of BE LIKE.

We therefore coded all quotative forms in the $M P F$ corpus for the content of the quote. The factors included internal monologue, as in (38), direct speech or constructed dialogue, (39), and non-lexicalised sound or gesture, $(40)^{6}$. We also coded for hypothetical quotes, including here quotes that are unlikely to have been uttered but that could be attributed to speakers based on their attitude and/or their behaviour. Sometimes grammatical cues indicated that the quote was imagined rather than uttered, as in (41), where DIRE is in the conditional mood.

(38) je me suis dit "ça c'est pas lui”" (Aisatta)

(39) après j'ai dit "non vas-y laisse tomber" (Letitia)

(40) moi j'ai failli vomir j’étais comme ça $<$ vomiting noises $>$ (Elisa)

(41) on dirait des gamins genre "non j'ai pas deux ans" (Letitia) 
A second classic factor for the use of English BE LIKE is grammatical person, with first person subjects consistently favouring its use in the early stages of its emergence as a quotative. Grammatical person is not relevant for quotative GENRE, since usually there is no supporting verb to carry the person (or tense) marking, so we ignored this factor in our analysis. We coded for the external factors of speaker sex as well as age, ethnicity and type of friendship network. We then performed a multivariate analysis of the effect of these factors, using mixed-effects logistic regression in Rbrul. Note that the total numbers entered into the analysis are lower than those seen in Table 1, since the analysis was based on only the 16 speakers who uttered the 20 tokens of quotative genre. Table 7 shows the factors selected as significant: factor weights (FW) above 0.5 favour the use of genre while those below 0.5 disfavour it.

\section{TABLE 7 HERE}

The 'classic factor' of content of the quote has the greatest effect (it has the highest range). The young speakers favour GENRE when they report hypothetical quotes, non-lexicalised sounds and gestures, and inner thought. They also prefer genre when they adopt a different voice (mimesis). In other words, they favour GENRE in the contexts that are well-attested for early uses of BE LIKE in English-speaking communities around the world. None of the social factors was found to be significant.

Comparing our results for GENRE with those for BE LIKE elsewhere in the world, then, shows that French and English 'similarity' quotatives enter the quotative system in the same way. The few other quantitative analyses of new quotatives in languages other than English find the same pattern. For example, in Ottawa French, 
mimetic re-enactment was a significant factor favouring ETRE COMME (Levey et al 2013); internal thought also favoured its use, though less strongly. In the Spanish of bilingual speakers in Texas, como, like genre, occurred far more frequently when introducing inner thought (91.3 per cent of the time, in fact) than when introducing direct speech (Kern 2014, 2017).

Our analysis adds to the mounting evidence, then, that similarity quotatives enter the quotative system of a language in a similar way, with their early use a direct reflection of the 'approximative' or 'similarity' meaning of the lexical item that grammaticalises into the new quotative.

\section{DEICTIC DEMONSTRATIVE QUOTATIVES}

We turn now to the other innovative quotative forms, those that include a deictic element: ETRE COMME ÇA and ETRE LA.

Quotations can be seen as 'demonstrations' of an original mimetic act (Clark and Gerrig 1990: 802); as Buchstaller (2014: 22) points out, 'by using lexical material with deictic semantics, reporting speakers can refer away from themselves, moving entirely into the background and simply pointing to the actors (or their speech acts) within the space of the reported narrative'. The result is that the act of reporting becomes a dramatic re-enactment of what took place, with the interlocutor's attention directed to the re-enacted action, allowing them to directly experience the original event (Buchstaller 2014: 154; Clark and Gerrig 1970: 793).

Seen from this perspective, each of the two deictic innovative quotatives directs attention to a different aspect of the act of quotation. The MPF speakers almost always use ETRE COMME CA, 'to be like that', to introduce a quote consisting of nonlexicalised sound: 11 of the 15 tokens in the corpus (73 per cent) are 
of this kind, representing, for example, the sounds made by a cat, crying or, as in (13) above, vomiting. Mimesis characterised just under half the quotes (46 per cent; 7 of the 15). Here, then, the deictic element, comme ça, draws attention specifically to the sound that speakers are about to perform: the focus is very clearly on the quote.

The $M P F$ speakers also use ETRE LA when they utter a quote with mimesis, and with quotes that are nonlexicalised sounds or gestures, or that report inner thought. Quoted sounds or gestures frequently describe inner thought, too, or emotional reactions to something that happened. In (42) and (43), for example, the speakers relate their terrified reaction to being asked to read aloud in German by their teacher. Secova (2015) gives a fuller account of the narrative of which these examples are part.

(42) moi j'étais là " <imitation pleurs, gestes>" (Maeva)

(43) ou sinon il fait “a ton tour de lire!” t’es là “ah euh euh” (Carla)

The particle là in present-day spoken French has a range of textual and interpersonal functions (Smith 1995, Dostie 2007). In Québec French là segments the discourse, highlighting the previous element and showing its relevance to what is to come next (Forget 1989:79, 80). It functions this way in the quotative expression ETRE LA too: là highlights and connects both the speaker and what the speaker utters. Unlike ETRE COMME CA, which focuses attention on the content of the quote, ETRE LA focuses on the entire act of quoting; but both expressions, in their different ways, allow a dramatic re-enactment of a scene.

Table 8 shows the results of a multivariate analysis aiming to determine the factors favouring the use of ETRE LA (the number of tokens of ETRE COMME CA 
was too low to allow quantitative analysis). Note, again, that the numbers entered into the analysis exclude speakers who did not use ETRE LA. The analysis is therefore based on only 12 speakers. The analysis confirms that ETRE LA is favoured when the content of the quote is non-lexicalised sound or internal thought, and when the quote is uttered with mimesis.

\section{TABLE 8 HERE}

Surprisingly, tense was also selected as a significant factor, with both the imperfect tense and the future tense favouring the use of ETRE LA. We assume that the selection of future tense simply reflects the lower frequency with which reporting verbs in general occur in the future tense. The selection of the imperfect tense, on the other hand, reflects the essentially descriptive function of the ETRE LA sequence: as mentioned, it focuses attention on the entire act of quoting (both the quoter and the quote). Interestingly, in the $M P F$ data the ETRE LA sequence also occurs with a nonquotative descriptive function, to describe the appearance, location, actions or activities of a protagonist, as in (44). Like ETRE LA with a quotative function, the sequence focuses attention on the entire scene. Note that it is not clear to what extent là retains a locative meaning when ETRE LA is used in this way.

(44) ils chantent en anglais et quand on connaît les chansons on est là on chante avec eux (Marie)

Often, ETRE LA occurs immediately before another quotative form, as in (45), where it introduces the entire quotative event ${ }^{7}$. 
(45) après les Marseillais ils étaient là ils pleuraient "vas -y vas-y vous avez trop de la chance vous gagnez" (Karim)

Table 9 shows that in Paris the non-quotative function of ETRE LA is almost as frequent as the quotative function - more frequent, in fact, if we include utterances such as (45) where it links a quotative expression with the speaker(s).

\section{TABLE 9 HERE}

We compared the use of the ETRE LA sequence by our sample of MPF speakers with its use by the 16 older speakers in CFPP2000 whose quotatives were discussed earlier. Since all ETRE LA tokens in the $M P F$ sample had a pronoun subject, we extracted only those tokens from older speakers where the subject was a pronoun (this was, in any case, almost all of them). None of the 73 ETRE LA tokens we extracted from the older CFPP2000 speakers were comparable to those found in the $M P F$ corpus; là was occasionally used as a textual anaphor, but in most cases it had a locative meaning, as in (46).

(46) la pauvre elle avait bien le droit d'être fiancée (rires) mais on considérait que non on était là pour faire des études et que on s'occuperait des garçons plus tard (Yvette Audin)

There are only three examples of quotative ETRE LA in CFPP2000, all from younger speakers ( 2 aged 25; 1 aged 15). Our analysis suggests, then, that use of the 
ETRE LA sequence as a way of focusing or dramatizing a reported scene is a recent development.

Although quotatives containing deictic elements are frequent crosslinguistically (Güldemann 2012), they are rarely reported as recent innovations ${ }^{9}$. However, one such quotative expression has recently emerged in Multicultural London English: THIS IS +speaker (Cheshire et al 2011). Unlike ETRE LA which, as we have seen, focuses on the entire act of quoting, the deictic element in THIS IS + speaker puts the emphasis on the source of the quote, a common strategy in the development of deictic quotatives (Güldemann 2012). Fox (2012) shows how young people in London use THIS IS + speaker to highlight a dramatic moment in a narrative, presenting the person who uttered the quote as a character in a quasitheatrical performance. THIS IS + speaker introduces only constructed dialogue, unlike ETRE LA, but an important similarity with ETRE LA is that it occurs with a non-quotative function, in a way that is related to its quotative function- in other words, it 'performs' the appearance, location, action or activities of a protagonist in a narrative. Thus in (47), from Cheshire et al (2011: 174), the speaker uses THIS IS + protagonist (or speaker) three times: first to direct attention to an action, then to a gesture and finally to direct attention to non-lexicalised sound, the dog's barking.

(47) alright right this is me knocking at the door yeah and I'm knocking at the door yeah and and this is the $\operatorname{dog}<$ gestures $>$ he went and this is the dog "woof woof woof" (Howard)

The two deictic quotatives, English THIS IS + speaker and French ETRE LA, then, have emerged in a similar way. Both have the general descriptive function of 
introducing dramatic re-enactments of a protagonist's behaviour, appearance or activities, including, crucially, their utterances. We assume that their appearance at roughly the same time is a coincidence, but the developmental pathway is similar.

No social factors were selected as significant for the ETRE LA quotative, not even type of friendship network. However, the numbers for this variant are very low. We combined tokens for all the innovative quotatives in the $M P F$ corpus in order to obtain a higher number of tokens (even so, they still amount to only 7 per cent of the entire set of quotative forms in the corpus). Table 10 shows the results: as is so often the case, female speakers lead overall in the use of the innovative forms.

\section{TABLE 10 HERE}

\section{DISCUSSION AND CONCLUSION}

De Smet (2016: 86) points out that linguistic innovations are intrinsically unlikely, and can only happen when a speaker 'defeats the odds' by selecting an expression that is unconventional in a particular grammatical context. This is more likely, he argues, if the 'deviation from convention is so minimal as to be (almost) undetectable' (ibid). The developmental pathways we have proposed for quotative GENRE and ETRE LA fit well with de Smet's proposals. For quotative genre, one such minimal deviation is the use of the noun genre with a phonetically reduced determiner, mentioned above with reference to $C F P P 2000$. Its prepositional-like use with no determiner at all, in a way that can be paraphrased as 'du genre', is a further small step. In (48), for example, genre could have been $d u$ genre, and the literal meaning of the phrase could have been 'there was also a thing of the pottery design type'. 
(48) y avait aussi euh plus un truc genre dessin poterie (Gabriel Pujade)

Once genre has lost its determiner, it is easy for speakers to no longer see it as a noun and for it to assume adverbial, discourse marker and discourse particle roles. As genre in new syntactic categories becomes more established, this provides support for further analogically related uses such as, in the case of genre, the quotative expression. Again, see de Smet (2016).

The prepositional use of genre also fits with De Smet's argument that innovations can happen only when the analogically related conventional expression is well established (op.cit.). The prepositional function of genre is not new. It is established enough in colloquial French for it to be included in dictionaries (for example, The Collins Robert French Dictionary 1987); and Isambert (2016: 88) notes that it occurs in an 1847 Balzac novel. From the prepositional use it is a further merely minimal deviation for genre, now freed from its determiner and, therefore, from its marking as a noun, to be used in other clause positions, as a discourse marker and discourse particle, and also before a quote. The meanings of approximation or similarity, already present in some uses of the noun genre (for example, with a following infinitival complement) are preserved in all these syntactic roles. Then, when the meaning has become bleached, presumably through frequent use as a discourse particle, genre can become used as a filler.

The development of ETRE LA as a quotative can, similarly, be seen in terms of minimal deviations from existing conventions. The particle là is used for focus and emphasis in many compound expressions; witness, for example, ici-là, là-dessous (Smith 1995, Dostie 2007). It is also used alone, as in (49). 
(49) si j'comparais à mon enfance où je me souviens d'avoir vu des gens très pauvres et ben là j'vous assure que vous y en a plein des gens très très pauvres (Jacqueline Pelletier)

It is a short step from using là for emphasis and focus, relating what has been said to what is about to be said, as in (49), to using it to highlight and connect a protagonist (the subject of the ETRE LA phrase) with a following reported activity or behaviour. This can include reported speaking, as we have argued above. Social factors do not appear to play a role in these small changes, at least not for the speakers in our sample.

We have not addressed the question of why the new French quotatives have emerged at this time, nor why young speakers of other languages are also using new quotative expressions. We assume that discourse style must be one important factor. It is not new, of course, for speakers to tell their interlocutors their inner thoughts, but what does seem to be new is to use direct quotation to dramatically re-enact internal, experiental experience. For New Zealand English, D'Arcy (2012:360-361) notes a correlation between the decade of a speaker's birth, since about 1900, and their use of direct quotation to report inner thought, with an accompanying increase in the number of different lexical items used to introduce this kind of quote. Research in the USA, Australia, England and Canada indicates that this seems to be a characteristic of speakers of English more generally (Buchstaller and D'Arcy 2009, D’Arcy 2012, Tagliamonte and D'Arcy 2007:211). Our data suggest that young speakers of French are using the new French quotatives in the same way. To return to the question we posed at the beginning of this article, if pragmatic borrowing is involved, it may be at the level of discourse style, perhaps disseminated via global communication flows. 
This is a question for future research: for now, we have simply set out the stages and the factors that we think are important in understanding the evolution of the new quotatives in French, and that may well apply cross-linguistically. We hope that future analyses of new quotatives in other languages, of which there are many, will put our hypotheses to the test.

*We would like to thank David Adger, Penelope Gardner-Chloros, Devyani Sharma and three anonymous referees for helpful and encouraging comments on an earlier draft of this paper.

\section{NOTES}

1. We identify speakers by the pseudonyms on the CFPP2000 website (first name plus family name), and retain the CFPP2000 transcription conventions.

2. At present, the two less frequent similarity quotatives seem to have specialised functions that relate to their uses as discourse markers. Secova (2011: 141) notes that as a discourse marker en mode is associated with descriptions of a state of mind or mood. In our data the quotative en mode, similarly, introduces imagined speech or thought associated with a state of mind or mood, as in the example below.

depuis tout à l'heure $\mathrm{j}(\mathrm{e})$ suis en mode "oh putain les trucs carrés j'arrive pas" alors ça $<$ rire $>$ ! (Suzanne) 
Secova finds that as a discourse marker, style is associated with false or ironic contexts, especially in descriptions of people's behaviour or appearance. Our one example of FAIRE STYLE introduces a quote that the speaker thinks is false:

et ils font style (.) " oh la la c'est trop simple ils ont des massages des masques et tout" [= imitation] alors que c'est pas du tout ça . (Annabelle)

3. The $M P F$ data was transcribed using the CHAT-Childes transcription conventions (childes.psy.cmu.edu/manuals/CHAT.pdf, pp. 41-80); the information in angled brackets includes metalinguistic comments, while round brackets represent different lengths of timed pause. Unclear speech is shown as ' $\mathrm{xxx}$ '. Speaker pseudonyms are first names only, to differentiate examples from the $M P F$ corpus from those from CFPP2000.

4. We thank an anonymous reviewer for this point.

5. We adopt D'Arcy's (2005) distinction between a discourse marker, which occurs at the periphery of the clause with scope over the entire clause, and a discourse particle, which has narrow scope over an element within the clause.

6. The majority of the recordings were transcribed by the interviewer (Maria Secova) soon after the interviews, so that details of the conversation, including gestures, could be easily remembered (however, non-lexicalised sounds were far more frequent than gestures). Both non-lexicalised sounds and gestures were tagged in the transcriptions. 
We coded separately for mimesis, including in this category a clear change in voice quality and a change of accent, pitch, volume or sound effects.)

7. Tokens like these were not included in the quantitative analyses, as être là did not immediately precede the quote.

8. In Québec, too, ETRE LA as both a quotative and a non-quotative expression may be a recent development: a search for j'étais là in the CFPQ (Corpus de français parlé au Québec, https://recherche.flsh.usherbrooke.ca/cfpq/index.php/site/index) extracted 57 tokens, of which 30 (53 per cent) were quotatives. All the quotatives came from speakers in their 20 s or younger (we thank a second reviewer for pointing us to quotative ETRE LA in this corpus). GENRE and ETRE COMME might be relatively recent developments in Québec, too, as neither they nor ETRE LA were mentioned in the seminal work by Vincent and Dubois (1997) based on corpora from 1971 and 1984.

\section{REFERENCES}

Aijmer, K. (2002). English discourse particles: Evidence from a corpus. Amsterdam: John Benjamins.

Andersen, G. (2014). Pragmatic borrowing. Journal of Pragmatics, 67:17-33.

Pragmatic markers and sociolinguistic variation. Amsterdam: Benjamins.

Bogetić, K. (2014). Be like and the quotative system of Jamaican English: Linguistic trajectories of globalization and localization. English Today, 30:5-12.

Branca-Rosoff, S., Fleury S., Lefeuvre F., and Pires M. (2012). Discours sur la ville. Présentation du Corpus de Français Parlé Parisien des années 2000 
(CFPP2000); http://cfpp2000.univ-paris3.fr, accessed 1.9.16.

Buchstaller, I. (2001). An alternative view of LIKE: its grammaticalisation in conversational American English and beyond. Edinburgh Working Papers in Applied Linguistics, 11:21-41.

Buchstaller, I. (2006). Diagnostics of age-graded linguistic behaviour: The case of the quotative system. Journal of Sociolinguistics, 10:3-30.

Buchstaller, I. (2014). Quotatives: New trends and sociolinguistic implications. Oxford: Wiley Blackwell.

Buchstaller, I. and D’Arcy, A. (2009). Localised globalization: A multi-local, multivariate investigation of quotative be like. Journal of Sociolinguistics, 13: 291-331.

Buchstaller, I. and van Alphen, I. (eds.). (2012). Quotatives: Cross-Linguistic and Cross-Disciplinary Perspectives Amsterdam: Benjamins.

Cheshire, J. and Fox, S. (2007). Innovation in the quotative system of London adolescents: The emergence of this is me. Paper presented at NWAV 36, University of Pennsylvania, October 122007.

Cheshire, J., Kerswill, P., Fox, S. and Torgersen, E. (2011). Contact, the feature pool and the speech community: the emergence of Multicultural London English. Journal of Sociolinguistics, 15:151-198.

Clark, H. and Gerrig, R. (1990). Quotations as demonstrations. Language, 66: 764-895.

Danon-Boileau, L. and Morel, M-A. (1997). "Question, point de vue, genre, style: les noms prépositionnels en français contemporain." Faits de langue, 9:192-200. 
D’Arcy, A. (2005). Like: Syntax and development. Unpublished PhD dissertation, University of Toronto.

D’Arcy, A. (2012) The diachrony of quotation: Evidence from New Zealand English. Language Variation and Change 24: 343-369.

Davidse, K., Brems, L., Willemse, P., Doyen, E., Kiermeer, J. and Thoelen, El. (2013). A comparative study of the grammaticalized uses of English "sort of" and French "genre (de)" in teenage forum data. In E. Piola (ed.) Languages go Web. Standard and non-standard languages on the internet. Alessandria: Edizione dell’Orso, pp. 41-66.

Davidse, K. and Doyen, E. (2009). Using teenage versus adult forum data for the study of language change: Is the grammaticalization of French genre as advanced as English sort and kind? In S. Slembrouck, M. Taverniers and M. van Herreweghe (eds.) From Will to Well: Studies in Linguistics, Offered to Anne-Marie Simon-Vandenbergen. Gent: Academia Press, pp.135-145.

De Smet, H. (2016). How gradual change progresses: The interaction between convention and innovation. Language Variation and Change, 28:83-102.

Diewald, G. (2006). Hecken und Heckenausdrücke - Versuch einer Neudefinition. In E. Calaresu, C. Guardiano and K. Hölker (eds.) Italienisch und Deutsch als Wissenschaftssprachen. Bestandsaufnahmen, Analysen, Perspektiven. Berlin: LIT-Verlag, pp. 295-315.

Dostie, G. (2007). La reduplication prgmatique des marquers discursifs. De là à là là. Langue Française, 154:45-6.

Dufaye, L. (2016). GENRE ou le scénario d'une grammaticalisation. Linx: bulletin $d u$ Centre de recherches linguistique de Paris X Nanterre. Centre de recherches linguistiques de Paris 10, pp. 45-59. 
Fernández, J. (2017). The language functions of tipo in Argentine vernacular. Journal of Pragmatics, 114:87-103.

Fleischmann, S. (1999). Pragmatic markers in comparative and historical perspective: Theoretical implications of a case study. Paper presented at the 14th International Conference on Historical Linguistics, August 9-13, Vancouver, Canada.

Fleischmann, S. and Yaguello, M. (2004) Discourse markers across languages. In C. Moder and A. Martinovic-Zic (eds.) Discourse across Languages and Cultures. Amsterdam: John Benjamins, pp. 129-147.

Forget, D. (1989). Là: un marquer de pertinence discursive. Revue québécoise de linguistique, 18:57-82.

Fox, S. (2012). Performed Narrative: the Pragmatic Function of this is + speaker and other quotatives in London adolescent speech. In I. Buchstaller and I. van Alphen (eds.). Quotatives: Cross-Linguistic and Cross-Disciplinary Perspectives Amsterdam: Benjamins, pp. 231-157.

Fox, B and Robles, J. (2010). It's like mmm: Enactments with it's like. Discourse Studies, 12:715-738.

Gadet, F. (ed.) (2017). Les parlers jeunes dans l'Île de France multiculturelle. Paris: Editions Ophrys.

Gardner-Chloros, P., Cheshire, J. and Secova, M. (2010-2014) Multicultural London English-Multicultural Paris French. Economic and Social Research Project RES062-33-0006.

Güldemann, T. (2001) Quotative constructions in African languages: A synchronic and diachronic survey. Unpublished Habilitationsschrift, University of Leipzig. 
Güldemann, T. (2012). Speaker-predicating quotative indexes: a first survey. In I. Buchstaller and I. van Alphen (eds.). Quotatives: Cross-Linguistic and CrossDisciplinary Perspectives. Amsterdam: Benjamins, pp. 117-142.

Haddican, W., Zweig, E. and Johnson, D. E. (2015) Change in the syntax and semantics of be like quotatives. In T. Biberaur and G. Walkden (eds.) Syntax over Time. Lexical, Morphological, and Information-Structural Interactions. Oxford: Oxford University Press, pp. 54-71.

Hasund, I. K., Opsahl, T. and Svennevig, J. (2012). By three means: The pragmatics of three Norwegian quotatives. In I. Buchstaller and I. van Alphen (eds.) Quotatives: Cross-linguistic and cross-disciplinary perspectives. Amsterdam: John Benjamins, pp. 37-70.

Heath, J. (1984) Language contact and language change. Annual Review of Anthropology, 13:367-384.

Höhn, N. (2012) “And they were all like 'What's going on?”” New quotatives in Jamaican English. In M. Hundt and U. Gut (eds.) Mapping unity and diversity worldwide in corpus-based studies of New Englishes. Amsterdam: Benjamins, pp. 263-290.

Isambert, P. (2016). Genre: une mode récente mais qui vient de loin. Journal of French Language Studies, 26:85-96.

Kern, J. (2014) Como in commute: The travels of a discourse marker across language. Studies in Hispanic and Lusophone Linguistics, 7:275-298.

Kern, J. (2017) Unpacking the variable context of quotatives. Evidence from U.S. Southwest Spanish. Spanish in Context 14:124-143. 
Levey, S. (2007). The next generation: Aspects of grammatical variation in the speech of some London preadolescents. Unpublished $\mathrm{PhD}$ dissertation, Queen Mary, University of London.

Levey, S., Groulx, K. and Roy, J. (2013). A variationist perspective on discoursepragmatic change in a contact setting. Language Variation and Change, 25:225251.

Levey, S. and Prazeres, R. (f-c) Quotative variation in comparative perspective: The view from Canadian French.

Macaulay, R. 2001. "You're Like 'Why Not?"' The quotative expressions of Glasgow adolescents. Journal of Sociolinguistics, 5:3-21.

Marchessou, A. (this issue). Neuhof - another setting for sociolinguistic variation in contemporary French.

Marnette, S. (2006). La signalisation du discours rapporté en français medieval. Langue Française, 149:31-47.

Matras, Y. (2011). Grammaticalization and language contact. In H. Narrog and B. Heine (eds.) The Oxford Handbook of Grammaticalization. Oxford: Oxford University Press, pp. 279-290.

Mihatsch, W. (2007). The construction of vagueness: sort of expressions in Romance languages. In G. Radden, K.-M. Köpke, T. Berg and P. Siemund (eds.) Aspects of meaning construction. Amsterdam: Benjamins, pp. 225-245.

Palacios Martínez, I. M. (2014). The quotative system in Spanish and English youth talk. A contrastive corpus-based study. Miscelánea, 49:95-114.

Petersen, E. (2017). The nativization of pragmatic borrowings in remote language contact situations. Journal of Pragmatics 113: 116-126. 
Poplack, S., Zentz, L. and Dion, N. (2012). What counts as [contact-induced] change? Bilingualism: Language and Cognition, 15:247-254.

Rosenkvist, H. and Skärlund, S. (2011). Grammatikalisering i nutid - utvecklingen av typ fram till 2009. Ur Språk \& stil NF, 21:5-25.

Secova, M. (2011). Discourse- pragmatic features of spoken French: analysis and pedagogical implications. Unpublished PhD thesis, Queen Mary University of London.

Secova, M. (2015). Discours direct chez les jeunes : nouvelles structures, nouvelles fonctions. Langage et Société, 151:131-151

Smith, J. C. (1995). L'évolution sémantique et pragmatique des adverbes déctiques ici, là et là-bas. Langue Française, 107:43-57.

Tagliamonte, S. and D'Arcy, A. (2004). He's like, she's like: The quotative system in Canadian youth. Journal of Sociolinguistics, 8:493-514.

Tagliamonte, S. and D'Arcy, A. (2005). When people say, "I was like...": the quotative system in Canadian youth. University of Pennsyvania Working Papers in Linguistics, 10 (2):257- 272.

Tagliamonte, S. and D'Arcy, A. (2007). Frequency and variation in the community grammar: Tracking a new change through the generations. Language Variation and Change, 19:199-217.

Tagliamonte, S. and D’Arcy, A. (2009). Peaks beyond phonology: adolescents, incrementation and language change. Language, 85:58-108.

Vincent, D. and Dubois, S. (1997). Le discours rapporté au quotidien. Québec: Nuit Blanche. 
Weinreich, U. (1964 [1953]). Languages in contact: Findings and problems. The Hague: Mouton.

Wiese, H. (2011). So as a focus marker in German. Linguistics, 49:991-1039.

Yaguello, M. 1998. Genre, une particule d'un genre nouveau. Petits faits de langue. Paris: Editions du Seuil, pp.18-24.

Address for correspondence:

Jenny Cheshire

Department of Linguistics

Queen Mary University of London

Mile End Road

London E1 4NS

UK

j.1.cheshire@qmul.ac.uk 
Table 1. Percentage $(\mathrm{N})$ of quotative forms used by older and younger speakers in Paris

\begin{tabular}{|l|l|l|}
\hline & $\begin{array}{l}\text { CFFP2000 older } \\
\text { speakers, born } \\
1923-1948\end{array}$ & $\begin{array}{l}\text { MPF speakers, } \\
\text { born 1995-2001 }\end{array}$ \\
\hline DIRE & $77.6(139)$ & $41.3(423)$ \\
\hline zero & $9.5(17)$ & $12.4(127)$ \\
\hline SE DIRE & $5 \quad(9)$ & $3.0(31)$ \\
\hline FAIRE & $0.5 \quad(1)$ & $29.7(304)$ \\
\hline c'est/c'était & $1 \quad(2)$ & $1.5(15)$ \\
\hline DIRE genre & & $0.4(4)$ \\
\hline $\begin{array}{l}\text { FAIRE } \\
\text { genre }\end{array}$ & & $0.4(4)$ \\
\hline genre & & $2.0(20)$ \\
\hline en mode & & $0.6(6)$ \\
\hline $\begin{array}{l}\text { FAIRE } \\
\text { STYLE }\end{array}$ & & $0.1(1)$ \\
\hline ETRE LA & & $2.6(27)$ \\
\hline $\begin{array}{l}\text { ETRE } \\
\text { COMME } \\
\text { CA }\end{array}$ & & $1.3(13)$ \\
\hline others & $5.6(10)$ & \\
\hline TOTAL & 179 & $4.7(48)$ \\
\hline
\end{tabular}




\begin{tabular}{|c|c|c|c|c|c|c|c|c|c|c|c|c|c|}
\hline & $\begin{array}{l}\text { binomial } \\
\text { noun } \\
\text { genre }\end{array}$ & $\begin{array}{l}\text { simple } \\
\text { noun }\end{array}$ & $\begin{array}{l}\text { fixed } \\
\text { expression }\end{array}$ & $\begin{array}{l}\text { preposition } \\
\text { genre }\end{array}$ & $\begin{array}{l}\text { genre } \\
\text { +infinitive }\end{array}$ & $\begin{array}{l}\text { adverbial } \\
\text { genre }\end{array}$ & $\begin{array}{l}\text { discourse } \\
\text { marker } \\
\text { genre }\end{array}$ & $\begin{array}{l}\text { discourse } \\
\text { particle } \\
\text { genre }\end{array}$ & $\begin{array}{l}\text { quotative } \\
\text { genre }\end{array}$ & $\begin{array}{l}\text { c'est } \\
\text { genre }\end{array}$ & $\begin{array}{l}\text { genre } \\
\text { que }\end{array}$ & $\begin{array}{l}\text { filler } \\
\text { genre }\end{array}$ & Total \\
\hline $\begin{array}{l}\text { born } \\
1920- \\
1929(1 \\
\text { speaker })\end{array}$ & $100(1)$ & & & & & & & & & & & & 1 \\
\hline $\begin{array}{l}\text { born } \\
1920- \\
1939(3 \\
\text { speakers) }\end{array}$ & $\begin{array}{l}91.8 \\
(11)\end{array}$ & & & $8.3(1)$ & & & & & & & & & 12 \\
\hline $\begin{array}{l}\text { born } \\
1940- \\
1949(6 \\
\text { speakers }) \\
\end{array}$ & $41.7(5)$ & $\begin{array}{l}16.7 \\
(2)\end{array}$ & $25.0(3)$ & & $8.3(1)$ & & & $8.3(1)$ & & & & & 12 \\
\hline $\begin{array}{l}\text { born } \\
1950- \\
1959(4 \\
\text { speakers })\end{array}$ & $\begin{array}{l}64.7 \\
(11)\end{array}$ & $\begin{array}{l}11.8 \\
(2)\end{array}$ & & $17.6(3)$ & $5.6(1)$ & & & & & & & & 17 \\
\hline $\begin{array}{l}\text { born } \\
1960- \\
1969(2 \\
\text { speakers })\end{array}$ & $\begin{array}{l}94.1 \\
(16)\end{array}$ & & & $5.6(1)$ & & & & & & & & & 17 \\
\hline $\begin{array}{l}\text { born } \\
1970- \\
1979(6 \\
\text { speakers })\end{array}$ & $46.2(6)$ & & $7.7(1)$ & $7.7(1)$ & $7.7(1)$ & $7.7(1)$ & & $7.7(1)$ & $7.7(1)$ & $7.7(1)$ & & & 13 \\
\hline $\begin{array}{l}\text { born } \\
1980-\end{array}$ & $\begin{array}{l}51.6 \\
(17)\end{array}$ & $3.0(1)$ & & $6.1(2)$ & $3.0(1)$ & $6.1(2)$ & $9.1(3)$ & $12.1(4)$ & $3.0(1)$ & $6.1(2)$ & & & 33 \\
\hline
\end{tabular}




\begin{tabular}{|c|c|c|c|c|c|c|c|c|c|c|c|}
\hline $\begin{array}{l}1989 \text { ( } 8 \\
\text { speakers) }\end{array}$ & & & & & & & & & & & \\
\hline $\begin{array}{l}\text { born } \\
1990- \\
1995(3 \\
\text { speakers }\end{array}$ & $4.5(1)$ & $4.5(1)$ & $4.5(1)$ & & $27.3(6)$ & $27.3(6)$ & $31.8(7)$ & & & & 22 \\
\hline $\begin{array}{l}M P F \\
\text { speakers } \\
\text { (born } \\
1995- \\
20 x x\end{array}$ & $2.6(13)$ & & $2.8(14)$ & $2.6(13)$ & $\begin{array}{l}58.1 \\
(287)\end{array}$ & $18.4(91)$ & $4.1(20)$ & $7.5(37)$ & $\begin{array}{l}0.4 \\
(2)\end{array}$ & $\begin{array}{l}3.4 \\
(17)\end{array}$ & 494 \\
\hline
\end{tabular}

Table 2. Percentage (n) syntactic function of genre relative to all genre tokens in CFFP2000 and the MPF corpus 


\begin{tabular}{|l|l|l|l|}
\hline & Total NP-internal & Total NP-external & Total no. genre \\
\hline $\begin{array}{l}\text { born 1920-1929 } \\
\text { (1 speaker) }\end{array}$ & $\begin{array}{l}\mathbf{1 0 0} \\
\mathbf{( 1 )}\end{array}$ & $\mathbf{0 . 0}$ & 1 \\
\hline $\begin{array}{l}\text { born 1920-1939 } \\
\text { (3 speakers) }\end{array}$ & $\mathbf{1 0 0 ( 1 2 )}$ & $\mathbf{0 . 0}$ & 12 \\
\hline $\begin{array}{l}\text { born 1940-1949 } \\
\text { (6 speakers) }\end{array}$ & $\mathbf{9 1 . 8 ( 1 1 )}$ & $\mathbf{8 . 3 ( 1 )}$ & 12 \\
\hline $\begin{array}{l}\text { born 1950-1959 (4 } \\
\text { speakers }\end{array}$ & $\mathbf{1 0 0 ( 1 7 )}$ & $\mathbf{0 . 0}$ & 17 \\
\hline $\begin{array}{l}\text { born 1960-1969 (2 } \\
\text { speakers) }\end{array}$ & $\mathbf{1 0 0 ( 1 7 )}$ & $\mathbf{0 . 0}$ & 17 \\
\hline $\begin{array}{l}\text { born 1970-1979 (6 } \\
\text { speakers) }\end{array}$ & $\mathbf{6 9 . 2 ( 9 )}$ & $\mathbf{3 0 . 8 ( 4 )}$ & 13 \\
\hline $\begin{array}{l}\text { born 1980-1989 (8 } \\
\text { speakers) }\end{array}$ & $\mathbf{6 3 . 6 ( 2 1 )}$ & $\mathbf{3 6 . 4 ~ ( 1 2 )}$ & 33 \\
\hline $\begin{array}{l}\text { born 1990-1995 (3 } \\
\text { speakers }\end{array}$ & $\mathbf{1 3 . 6 ( 3 )}$ & $\mathbf{8 6 . 4 ( 1 9 )}$ & 22 \\
\hline $\begin{array}{l}\text { MPF speakers (born } \\
\text { 1992-1999 }\end{array}$ & $\mathbf{5 . 5 ( 2 7 )}$ & $\mathbf{9 4 . 5 ( 4 6 7 )}$ & 494 \\
\hline
\end{tabular}

Table 3. Percentage (n) NP-internal and NP-external uses of genre 


\begin{tabular}{|l|l|}
\hline Syntactic role or collocation & Number of occurrences \\
\hline $\begin{array}{l}\text { discourse marker after DIRE or } \\
\text { FAIRE }\end{array}$ & 8 \\
\hline $\begin{array}{l}\text { discourse marker after an } \\
\text { adjective }\end{array}$ & 2 \\
\hline other discourse marker uses & 7 \\
\hline preposition & 3 \\
\hline noun & 1 \\
\hline demonstrative + genre & 1 \\
\hline c'est construction & 1 \\
\hline ETRE + genre & 1 \\
\hline
\end{tabular}

Table 4. Quotative GENRE in the MPF corpus

\begin{tabular}{|l|l|l|}
\hline corpus & Date of birth of speakers & $\begin{array}{l}\text { Frequency of discourse } \\
\text { marker genre per } 1000 \\
\text { words }\end{array}$ \\
\hline $\begin{array}{l}\text { CFPP2000; speakers aged } \\
60+\end{array}$ & c. 1940 & 0.03 \\
\hline $\begin{array}{l}\text { CFPP2000; speakers aged } \\
15-30\end{array}$ & c. $1980-95$ & 0.33 \\
\hline $\begin{array}{l}M P F \text { corpus; speakers } \\
\text { aged } 12-19\end{array}$ & c. 1996 & 0.8 \\
\hline
\end{tabular}

Table 5. Frequency per 1000 words of discourse marker genre in Paris 
Table 6. Frequency per 1000 words of discourse marker like in London

\begin{tabular}{|l|l|l|}
\hline corpus & Date of birth of speakers & $\begin{array}{l}\text { Frequency of discourse } \\
\text { marker like per } 1000 \\
\text { words }\end{array}$ \\
\hline $\begin{array}{l}\text { Linguistic Innovators } \\
\text { corpus; speakers aged 70+ }\end{array}$ & c. 1958 & 1.8 \\
\hline $\begin{array}{l}\text { COLT (Corpus of London } \\
\text { Teenage Speech) }\end{array}$ & c. 1978 & 7.8 \\
\hline $\begin{array}{l}\text { Linguistic Innovators } \\
\text { corpus; speakers aged 16- } \\
19\end{array}$ & c. 1988 & 14.8 \\
\hline
\end{tabular}

Table 7. Contribution of factors to the use of the quotative GENRE in the MPF corpus

\begin{tabular}{|c|c|c|c|}
\hline \multicolumn{4}{|c|}{ GENRE } \\
\hline Input & \multicolumn{2}{|c|}{0.06} & \\
\hline \multirow[t]{2}{*}{ Total N } & \multicolumn{2}{|c|}{359} & \\
\hline & FW & $\%$ & $n$ \\
\hline \multicolumn{4}{|l|}{ Content } \\
\hline Hypothetical quotes & .74 & 16 & $10 / 61$ \\
\hline Non-lexicalised sounds and gestures & .71 & 27 & $4 / 15$ \\
\hline Internal monologue & .66 & 12 & $5 / 42$ \\
\hline Direct speech & .07 & 0.4 & $1 / 241$ \\
\hline Range & 67 & & \\
\hline \multicolumn{4}{|l|}{ Mimesis } \\
\hline Yes & .69 & 14 & $15 / 108$ \\
\hline No & .31 & 2 & $5 / 251$ \\
\hline Range & 38 & & \\
\hline
\end{tabular}




\begin{tabular}{|c|c|c|c|}
\hline \multicolumn{4}{|c|}{ ETRE LA } \\
\hline Input & \multicolumn{2}{|c|}{0.32} & \\
\hline Total N & \multicolumn{2}{|c|}{208} & \\
\hline & FW & $\%$ & $n$ \\
\hline \multicolumn{4}{|l|}{ Content } \\
\hline Non-lexicalised sounds and gestures & .81 & 77 & $10 / 13$ \\
\hline Internal monologue & .60 & 44 & $7 / 16$ \\
\hline Hypothetical quotes & .40 & 14 & $3 / 21$ \\
\hline Direct speech & .18 & 4 & $7 / 158$ \\
\hline Range & \multicolumn{3}{|l|}{63} \\
\hline \multicolumn{4}{|l|}{ Temporal reference } \\
\hline Imperfect & .80 & 57 & $17 / 30$ \\
\hline Future & .54 & 23 & $3 / 13$ \\
\hline Present & .18 & 4 & $7 / 165$ \\
\hline Range & 62 & & \\
\hline \multicolumn{4}{|l|}{ Mimesis } \\
\hline Yes & .74 & 43 & $23 / 54$ \\
\hline No & .27 & 3 & $4 / 154$ \\
\hline Range & 47 & & \\
\hline
\end{tabular}

Table 8. Contribution of factors to the use of the quotative ETRE LA

\begin{tabular}{|l|l|}
\hline \multicolumn{1}{|c|}{ ETRE LA } & $\begin{array}{l}\text { Percentage (n) of } \\
\text { all ETRE LA forms }\end{array}$ \\
\hline quotative use & $46(27)$ \\
\hline introduces a quotative & $17(10)$ \\
\hline non-quotative use & $37(22)$ \\
\hline
\end{tabular}

Table 9. Quotative and non-quotative uses of ETRE LA 


\begin{tabular}{|l|l|l|l|l|}
\hline Variant & Traditional variants & Innovative variants & \% Innovative & Total \\
& $\begin{array}{l}\text { (DIRE, DEMANDER, } \\
\text { SE DIRE, FAIRE, } \\
\text { c'est, zero, other) }\end{array}$ & $\begin{array}{l}\text { (ETRE LÀ, ETREE } \\
\text { COMME ÇA, } \\
\text { GENRE, DIRE / } \\
\text { FAIRE genre, EN } \\
\text { MODE, STYLE })\end{array}$ & & \\
& & 65 & & \\
& & 10 & \\
\hline Female & 570 & 10 & 3 & 635 \\
\hline Male & 387 & $\mathbf{7 5}$ & $\mathbf{7}$ & $\mathbf{1 0 3 2}$ \\
\hline Total & $\mathbf{9 5 7}$ & &
\end{tabular}

Chi-square 21.5876, df $1, p<.00001$.

Table 10. Distribution of innovative variants according to speaker sex 